\title{
Feeding Zinc-Biofortified Wheat Improves Performance, Nutrient Digestibility, and Concentrations of Blood and Tissue Minerals in Quails
}

\author{
Nurhan Sahin ${ }^{1}$ (D) Osman Kucuk ${ }^{2}$ (D) $\cdot$ Cemal Orhan $^{1}$ (D) $\cdot$ Erdinc Savasli $^{3}$ (D) Ismail Cakmak ${ }^{4}$ (D) Kazim Sahin ${ }^{1}$ (D)
}

Received: 25 August 2021 / Accepted: 4 October 2021 / Published online: 12 October 2021

(c) The Author(s), under exclusive licence to Springer Science+Business Media, LLC, part of Springer Nature 2021

\begin{abstract}
The present study aimed to investigate the effects of feeding zinc ( $\mathrm{Zn}$ )-biofortified wheat on performance, digestibility, and concentrations of minerals in quails. Zinc biofortification of wheat has been realized in the field by ergonomically applying $\mathrm{Zn}$ to foliar two and three times, which increased grain Zn from $18 \mathrm{mg} / \mathrm{kg}$ (control) to 34 and $64 \mathrm{mg} / \mathrm{kg}$. A total of 180 quails were divided into six groups, each containing 30 birds, and fed diets containing wheat grain with either 18, 34, or $64 \mathrm{mg} / \mathrm{kg}$ with or without zinc picolinate (ZnPic) supplementation. Bodyweight, feed intake, feed efficiency, and cold carcass weights were greater $(P=0.0001)$ when the quails were fed a diet containing the biofortified wheat-containing $64 \mathrm{mg} \mathrm{Zn} / \mathrm{kg}$. Nitrogen, ash, $\mathrm{Ca}, \mathrm{P}, \mathrm{Zn}, \mathrm{Cu}$, and Fe retentions were greater with the $\mathrm{Zn}$-biofortified wheat-containing $64 \mathrm{mg} \mathrm{Zn} / \mathrm{kg}(P \leq 0.026)$. The nutrient excretions were low with feeding a diet containing biofortified wheat-containing $64 \mathrm{mg} \mathrm{Zn} / \mathrm{kg}(P \leq 0.023)$. Serum, liver, and heart $\mathrm{Zn}$ concentrations increased with feeding biofortified wheat-containing $64 \mathrm{mg} \mathrm{Zn} / \mathrm{kg}(P \leq 0.002)$. Thigh meat Fe concentrations increased with increasing $\mathrm{Zn}$ concentrations of the wheat samples used $(P=0.0001)$, whereas the liver $\mathrm{Cu}$ concentrations decreased with feeding the wheat-containing $64 \mathrm{mg} \mathrm{Zn} / \mathrm{kg}(P=0.004)$. The Zn-biofortified wheatcontaining greater $\mathrm{Zn}$ concentrations, particularly $64 \mathrm{mg} \mathrm{Zn} / \mathrm{kg}$, is a good replacement for corn in the poultry diet as long as its availability and low cost for better performance, greater digestibility, and elevated tissue $\mathrm{Zn}$ and Fe concentrations.
\end{abstract}

Keywords Zn-biofortified wheat - Zinc picolinate $\cdot$ Performance $\cdot$ Digestibility $\cdot$ Quail

\section{Introduction}

Zinc $(\mathrm{Zn})$ is an essential trace element for humans and animals, including poultry. The importance of $\mathrm{Zn}$ in animal nutrition, particularly in poultry, comes from its necessity for growth (live performance), immunity, bone development, feathering, appetite, skin health, gene regulation, antioxidant

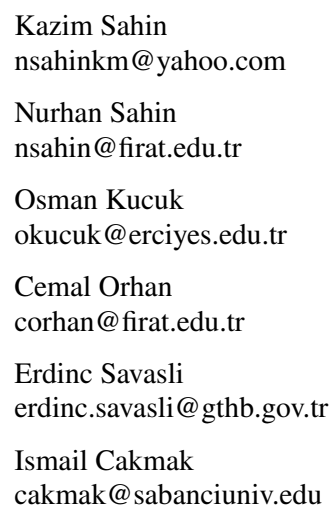

defense, reproduction, and fast absorption [1-4]. Zinc has critical functions in immune response in the human body against various bacterial and viral attacks such as coronaviruses [5]. Zn also has particular structural and physiological processes in about $10 \%$ of the human proteins [6].

Cereals such as wheat, rice, and maize are relatively low in $\mathrm{Zn}$ contents (26-35 mg Zn/kg dry matter (DM) compared

1 Department of Animal Nutrition, Faculty of Veterinary Medicine, Firat University, Elazig 23119, Turkey

2 Department of Animal Nutrition and Nutritional Diseases, Faculty of Veterinary Medicine, Erciyes University, Kayseri 38039, Turkey

3 Transitional Zone Agricultural Research Institute, Eskisehir 26002, Turkey

4 Faculty of Engineering and Natural Sciences, Sabanci University, Istanbul 34956, Turkey 
with animal protein sources [2]. The requirement of $\mathrm{Zn}$ for optimum poultry growth up to 21 days has been reported to be $40-50 \mathrm{mg} \mathrm{Zn} / \mathrm{kg}$ DM [7, 8]. Therefore, a classical cereal-soybean meal-based diet of poultry requires a supplemental Zn. Dietary supplementation of $\mathrm{Zn}$ in poultry has been shown to provide better live performance and digestibility $[9,10]$.

Wheat (Triticum spp.) represents a significant part of the diet consumed in many countries, providing an ample proportion of energy and protein despite its low concentrations of minerals such as $\mathrm{Zn}$ and Fe [11, 12]. Therefore, $\mathrm{Zn}$ intake is restricted when a substantial part of the diet contains wheat which has a naturally low $\mathrm{Zn}$ concentration (20-40 mg Zn/kg DM) with poor bioavailability because of phytate-bound $\mathrm{Zn}$, resulting in deficiency symptoms including retarded growth and depressed immunity in humans [13] as well as in poultry $[14,15]$.

Zinc deficiency is probably the most common micronutrient deficiency in arable soils. Although soils are sufficiently rich in $\mathrm{Zn}$, the $\mathrm{Zn}$ in the soils is not chemically available for root absorption due to several adverse chemical and physical soil properties, including high soil $\mathrm{pH}$, low organic matter, and low soil moisture [16]. Previously, it has been reported that about $50 \%$ of the cultivated soils globally have a low amount of plant-available $\mathrm{Zn}$ [17]. Consequently, plants grown on these soils contain a low amount of $\mathrm{Zn}$ in edible parts. Recently, Hill et al. [18] reported that grazing animals are at high risk of reduced $\mathrm{Zn}$ intake because the pastures contain very low $\mathrm{Zn}$ due to the low amount of plant-available $\mathrm{Zn}$ in soils. Today, there is an increasing trend to enrich (biofortify) pasture and fodder with $\mathrm{Zn}$ to ensure better $\mathrm{Zn}$ nutrition of animals. One strategy used for biofortification of pastures is agronomic biofortification (i.e., application of Zn fertilizers) [12].

Today agronomic biofortification of food and feed crops with micronutrients, especially $\mathrm{Zn}$, is becoming very popular $[16,19,20]$. Compared to soil $\mathrm{Zn}$ application, foliar application of $\mathrm{Zn}$ fertilizers has been found to be highly effective in increasing grain $\mathrm{Zn}$ concentration [21]. In a recent human zinc absorption study, it has been shown that wheat biofortified with Zn by applying Zn had a distinct effect on dietary zinc absorption in humans, and this agronomic approach could help reduce the global burden of $\mathrm{Zn}$ deficiency [22].

Published reports show that among the interventions focusing on enrichment of foods or feeds with micronutrients, genetic biofortification (through classical breeding) and agronomic biofortification (through fertilizer applications) are similar or even more cost-effective than food fortification or supplementation for long term. In addition, there is also a high potential to improve the yield of plants in the field by applying micronutrient-containing fertilizers because soils are usually low in micronutrients, especially with $\mathrm{Zn}[16$, 20, 23].
To our knowledge, the effect of agronomically biofortified wheat on the growth and development of poultry has not been studied. In the present study, we first produced wheat grains containing three different $\mathrm{Zn}$ concentrations by applying $\mathrm{ZnSO}_{4}$ to foliar. These $\mathrm{Zn}$-biofortified wheat grains were then used to study their effects on performance, carcass characteristics, nutrient digestibility, and serum and tissue mineral concentrations in broiler-type quails.

\section{Materials and Methods}

\section{Wheat Grain Material}

In order to obtain wheat grains differing in $\mathrm{Zn}$ concentrations, bread wheat (Triticum aestivum) cultivar (Bezostaja) has been grown in Eskisehir, Central Anatolia in Turkey, as described by Cakmak et al. [21]. Wheat plants were sprayed with $\mathrm{ZnSO} 4$ either two times at the booting and milk stages or three times at the booting, anthesis, and milk stages. The control plots (no $\mathrm{Zn}$ application) were treated with water (see Cakmak et al. [21] for further details). The grains collected from the plots with different $\mathrm{Zn}$ applications were analyzed for $\mathrm{Zn}$. The analysis results showed the following grain $\mathrm{Zn}$ results: (i) $18 \mathrm{mg} \mathrm{Zn/kg}$ (no Zn spray), (ii) $34 \mathrm{mg}$ $\mathrm{Zn} / \mathrm{kg}$ (2 times $\mathrm{Zn}$ spray), and (iii) $64 \mathrm{mg} \mathrm{Zn/kg} \mathrm{(3} \mathrm{times}$ $\mathrm{Zn}$ spray). These grains were then used in the feeding trials described below.

\section{Birds, Diets, Experimental Design}

One hundred and eighty (one-day-old) Japanese quails (Coturnix coturnix japonica) were randomly divided into six equal groups, each containing 30 birds according to the body weights. Each group was subdivided into three replicates with ten birds. The birds were kept in cages with $20 \times 20 \mathrm{~cm}$ dimensions, providing a space of $400 \mathrm{~cm}^{2}$ per bird in a temperature-controlled room at $24 \pm 2{ }^{\circ} \mathrm{C}$ with 60 to $75 \%$ relative humidity.

The brooding temperature was $37.5^{\circ} \mathrm{C}$ during the first week of life, with a weekly decline of $3{ }^{\circ} \mathrm{C}$ until room temperature $\left(24-27{ }^{\circ} \mathrm{C}\right)$ was achieved. The photoperiod was $14 \mathrm{~h}$ light and $10 \mathrm{~h}$ dark (06.00-20.00 h). The birds were fed a starter diet until 21 days of age, followed by feeding a grower diet from day 21 to day 42 (Table 1). Feed and water were offered ad libitum throughout the experiment. The experiment was conducted in accordance with animal welfare regulations at the Veterinary Control and Research Institute of Elazig, Turkey (011/5-2).

All the diets were formulated based on the wheat-maizesoybean meal to meet or exceed NRC [24] requirements for quails and supplemented with the enzyme xylanase $(200 \mathrm{mg} /$ $\mathrm{kg}$ of feed; Ronozyme ${ }^{\circledR}$ WX (CT), also known as BioFeed ${ }^{\circledR}$ 
Table 1 Ingredients and chemical composition of the starter and grower diets fed to quails

\begin{tabular}{|c|c|c|}
\hline Item & $\begin{array}{l}\text { Starter } \\
0-21 \text { days }\end{array}$ & $\begin{array}{l}\text { Grower } \\
22-42 \text { days }\end{array}$ \\
\hline \multicolumn{3}{|l|}{ Ingredients, $\%$} \\
\hline Wheat* & 30.00 & 30.00 \\
\hline Maize & 28.22 & 34.35 \\
\hline Soybean meal (48\% CP) & 36.00 & 28.00 \\
\hline Soybean oil & 2.30 & 4.00 \\
\hline Calcium carbonate & 1.38 & 1.32 \\
\hline Dicalcium phosphate & 0.65 & 0.83 \\
\hline Salt, $\mathrm{NaCl}$ & 0.20 & 0.20 \\
\hline Sodium bicarbonate & 0.15 & 0.15 \\
\hline DL-methionine & 0.30 & 0.15 \\
\hline L-lysine & 0.10 & 0.30 \\
\hline L-threonine & 0.25 & 0.25 \\
\hline Enzyme & 0.20 & 0.20 \\
\hline Vitamin-minerals premix $* *$ & 0.25 & 0.25 \\
\hline \multicolumn{3}{|l|}{ Chemical composition } \\
\hline Metabolizable energy (ME) MJ/kg & 12.27 & 12.98 \\
\hline Crude protein $(\mathrm{CP}), \%$ & 24.18 & 21.00 \\
\hline Ash, $\%$ & 5.67 & 5.35 \\
\hline Ether extract, $\%$ & 4.09 & 5.84 \\
\hline Crude fiber, $\%$ & 2.92 & 2.75 \\
\hline Methionine-cystine, $\%$ & 1.09 & 0.85 \\
\hline Lysine, $\%$ & 1.33 & 1.27 \\
\hline $\mathrm{Ca}, \%$ & 0.80 & 0.80 \\
\hline $\mathrm{P}, \%$ & 0.30 & 0.30 \\
\hline
\end{tabular}

${ }^{*}$ Wheat varieties with three different zinc concentrations $(18 \mathrm{mg} / \mathrm{kg}$, $34 \mathrm{mg} / \mathrm{kg}$, and $64 \mathrm{mg} / \mathrm{kg} \mathrm{Zn}$ ) were used. Maize and soybean meal zinc concentrations were $15 \mathrm{mg} / \mathrm{kg}$ and $60 \mathrm{mg} / \mathrm{kg}$

** Vitamin-minerals premix (free of $\mathrm{Zn}$ ) provides the following per $\mathrm{kg}$ : all-trans-retinyl acetate, $1.8 \mathrm{mg}$; cholecalciferol, $0.025 \mathrm{mg}$; allrac-tocopherol acetate, $1.25 \mathrm{mg}$; menadione (menadione sodium bisulfate, $1.1 \mathrm{mg}$; riboflavin, $4 \mathrm{mg}$; thiamine (thiamine mononitrate), $1.1 \mathrm{mg}$; pyridoxine, $2.2 \mathrm{mg}$; niacin, $35 \mathrm{mg}$; Ca-pantothenate, $10 \mathrm{mg}$; vitamin B12, $0.02 \mathrm{mg}$; folic acid, $0.55 \mathrm{mg}$; d-biotin, $0.1 \mathrm{mg}$; $\mathrm{Mn}$ (from $\mathrm{MnO}$ ), $40 \mathrm{mg}$; $\mathrm{Fe}$ (from $\mathrm{FeSO} 4$ ), $12.5 \mathrm{mg}$; $\mathrm{Cu}$ (from $\mathrm{CuSO} 4$ ), $3.5 \mathrm{mg}$; I (from KI), $0.3 \mathrm{mg}$; Se (from NaSe), $0.15 \mathrm{mg}$; and cholinechloride, $175 \mathrm{mg}$

Wheat; DSM Nutritional Products, Kaiseraugst, Switzerland). The enzyme product contained a mono-component thermostable endo1,4-xylanase (EC 3.2.1.8) derived from Thermomyces lanuginosus, expressed in a genetically modified strain of Aspergillus oryzae. A coated dry product form of the enzyme was used with a minimum activity of 1000 FXU/g product (Farbe xylanase units).

The quails were fed regular diets including either (1) $18 \mathrm{mg}$ $\mathrm{Zn} / \mathrm{kg}$ DM-containing wheat along with no zinc picolinate (ZnPic) supplemented to the diet (W18), or (2) $18 \mathrm{mg} \mathrm{Zn/}$ $\mathrm{kg}$ DM-containing wheat along with $212.4 \mathrm{mg} / \mathrm{kg} \mathrm{ZnPic}$ supplemented to the diet (W18+Zn), or (3) $34 \mathrm{mg} \mathrm{Zn/kg}$
DM-containing wheat along with no ZnPic supplemented to the diet (W34), or (4) $34 \mathrm{mg} \mathrm{Zn/kg} \mathrm{DM-containing} \mathrm{wheat}$ along with $189.5 \mathrm{mg} / \mathrm{kg} \mathrm{ZnPic}$ supplemented to the diet (W34+Zn), or (5) $64 \mathrm{mg} \mathrm{Zn/kg} \mathrm{DM-containing} \mathrm{wheat} \mathrm{along}$ with no ZnPic supplemented to the diet (W64), or (6) $64 \mathrm{mg}$ $\mathrm{Zn} / \mathrm{kg}$ DM-containing wheat along with $146.7 \mathrm{mg} / \mathrm{kg} \mathrm{ZnPic}$ supplemented to the diet (W64+Zn). In the zinc-supplemented groups, dietary zinc levels were adjusted to $50 \mathrm{mg}$ $\mathrm{Zn} / \mathrm{kg}$ of diet by supplementing an organic source of $\mathrm{Zn}$ as $\mathrm{ZnPic}$ based on recommended doses [3, 7, 8]. The concentrations of zinc in the ingredients and diets are shown in Table 2.

\section{Data Collection}

Cumulative feed intakes and body weight gains were recorded weekly, and weight gains and feed efficiencies were calculated. At the end of the study (day 42), 12 birds (two per replicate) randomly chosen from each treatment group were slaughtered for carcass evaluations and analyses of sera and tissues, namely liver, heart, and thigh meat. The birds were not fed before slaughter, and carcasses were yielded by removing feathers (wet), feet, and visceral organs. Blood samples $(5 \mathrm{~mL})$ were centrifuged at $3000 \times g$ for $10 \mathrm{~min}$ for sera collection. The liver, heart, and left thigh were also removed for mineral analysis. The samples were stored at $-80^{\circ} \mathrm{C}$ until analyses.

At the last 7 days of the experiment, 6 birds from each group were placed into individual battery cages for excreta collection to measure the digestibility of nitrogen, ash, $\mathrm{Ca}, \mathrm{P}$, $\mathrm{Zn}, \mathrm{Cu}$, and $\mathrm{Fe}$. The excreta samples were oven-dried at $60{ }^{\circ} \mathrm{C}$ for $48 \mathrm{~h}$ and then ground to pass through a 40-mesh screen.

\section{Laboratory Analyses}

Feed and excreta samples were analyzed for crude protein (\#988.05) and crude ash (\#936.07) in triplicates [25]. Nutrient excretion ( $\mathrm{g} / \mathrm{bird}$ ) was determined according to analyzed nutrient concentration in the excreta produced during the 7 days. Nutrient retention (g/bird) was calculated as nutrient intake (g/bird) minus nutrient excretion ( $\mathrm{g} / \mathrm{bird})$. Nutrient retention (\%) indicates the percentage of nutrients retained by the bird as a function of nutrient intake, and it was calculated as follows:

Nutrient retention $(\%)=[$ nutrient retention $(\mathrm{g} /$ bird $) /$ nutrient intake $(\mathrm{g} /$ bird $)] * 100$

For detection of the concentrations of $\mathrm{Ca}, \mathrm{P}, \mathrm{Zn}, \mathrm{Cu}$, and $\mathrm{Fe}$ in feed, excreta, liver, heart, and thigh meat samples with $0.3 \mathrm{~g}$ each, along with $0.5 \mathrm{~mL}$ of serum samples, were weighed into a Teflon digestion vessel for digestion in $5 \mathrm{~mL}$ of $65 \%(\mathrm{v} / \mathrm{v})$ spectra pure $\mathrm{HNO}_{3}$ (Suprapur, Merck, Darmstadt, Germany) in the model Speedwave ${ }^{\text {TM }}$ MWS-2 Microwave Digestion System (Berghof, Eningen, Germany) which 
Table 2 The levels of $\mathrm{Zn}(\mathrm{mg} / \mathrm{kg})$ in the diets fed to quails*

\begin{tabular}{|c|c|c|c|c|c|}
\hline \multirow[t]{2}{*}{ Treatment groups } & \multirow[t]{2}{*}{ Zn from wheat } & \multirow[t]{2}{*}{$\mathrm{Zn}$ from $\mathrm{ZnPic}$} & \multirow{2}{*}{$\begin{array}{l}\text { Zn amount (calcu- } \\
\text { lated) }\end{array}$} & \multicolumn{2}{|c|}{ Zn amount (analyzed) } \\
\hline & & & & $0-21$ days & 22-42 days \\
\hline W18 & 5.4 & 0.0 & 5.4 & $31.3 \pm 1.1$ & $26.5 \pm 2.3$ \\
\hline $\mathrm{W} 18+\mathrm{ZnPic}$ & 5.4 & 44.6 & 50.0 & $76.4 \pm 2.5$ & $72.0 \pm 1.9$ \\
\hline W34 & 10.2 & 0.0 & 10.2 & $35.2 \pm 2.7$ & $33.5 \pm 1.0$ \\
\hline $\mathrm{W} 34+\mathrm{ZnPic}$ & 10.2 & 39.8 & 50.0 & $76.0 \pm 2.4$ & $71.3 \pm 2.9$ \\
\hline W64 & 19.2 & 0.0 & 19.2 & $43.8 \pm 2.1$ & $42.6 \pm 2.5$ \\
\hline $\mathrm{W} 64+\mathrm{ZnPic}$ & 19.2 & 30.8 & 50.0 & $77.2 \pm 1.6$ & $73.1 \pm 1.1$ \\
\hline
\end{tabular}

*The three different wheat varieties were included in the diet at $30 \%$. The $\mathrm{Zn}$ levels were adjusted to $50 \mathrm{mg} / \mathrm{kg}$ in each $\mathrm{Zn}$-supplemental diets by adding $212.4 \mathrm{mg} / \mathrm{kg} \mathrm{ZnPic} \mathrm{(44.6} \mathrm{mg} \mathrm{elemental} \mathrm{Zn),} 189.5 \mathrm{mg} / \mathrm{kg} \mathrm{ZnPic} \mathrm{(39.8} \mathrm{elemental} \mathrm{Zn),} \mathrm{and} 146.7 \mathrm{mg} / \mathrm{kg} \mathrm{ZnPic}$ (30.8 elemental Zn) for $\mathrm{W} 18+\mathrm{ZnPic}, \mathrm{W} 34+\mathrm{ZnPic}$ and $\mathrm{W} 64+\mathrm{ZnPic}$ groups, respectively. The supplemental ZnPic contains $21 \% \mathrm{Zn}$

was equipped with a temperature, time, and power according to the digestion program. Sample solutions were diluted with $0.2 \%$ (v/v) nitric acid plus $0.2 \%$ (v/v) Triton X-100. Ca, Zn, $\mathrm{Cu}$, and $\mathrm{Fe}$ concentrations were determined by flame atomic absorption spectrometry (F-AAS, AAS, Perkin-Elmer, Analyst 800 , Norwalk, CT). The accuracy of quantitative measurements of $\mathrm{Ca}, \mathrm{Zn}, \mathrm{Cu}$, and $\mathrm{Fe}$ was assured by simultaneous analysis of certified reference materials (NCS ZC730016 Chicken) which was digested analogously to the samples. The detection limits of $\mathrm{Ca}, \mathrm{Zn}, \mathrm{Cu}$, and $\mathrm{Fe}$ were 45.0, 3.8, 1.5 , and $0.3 \mu \mathrm{g} / \mathrm{L}$, respectively. The mean recoveries of the reference material for tissues were as follows: $\mathrm{Ca} 95 \%, \mathrm{Fe}$ $98 \%, \mathrm{Zn} 95 \%$, and $\mathrm{Cu} 99 \%$.

\section{Statistical Analyses}

Data were analyzed by one-way ANOVA using SPSS, 2012 Version 21.0. In addition, post hoc Tukey procedure was run for multiple comparisons of the groups. The Shapiro-Wilk test was used to test the normality of the data. $P<0.05$ was regarded statistically significant.

\section{Results}

Initial body weights of the quails were intended to be similar among treatments $(P>0.05)$. However, final body weights of the quails increased with the inclusion of greater $\mathrm{Zn}$ concentration of the biofortified-wheat samples in the diet, and additional ZnPic supplementation to each diet resulted in further but equal increases in final body weights $(P=0.0001$; Fig. 1A). Bodyweight gains, as a reflection of the net body weight changes, were greater with the inclusion of the biofortified wheat-containing $64 \mathrm{mg} \mathrm{Zn} / \mathrm{kg}$ DM to the diet compared with the other wheat samples $(P=0.0001)$, and supplementing $\mathrm{ZnPic}$ to each diet equally but further increased the body weight gains $(P=0.0001$, Fig. 1B). The quails consumed more of the diet containing the wheat sample with $64 \mathrm{mg} \mathrm{Zn} / \mathrm{kg}$ DM compared with other diets $(P=0.0001)$, and supplementing $\mathrm{ZnPic}$ to each diet equally but further increased feed intake $(P=0.0001$, Fig. 1C). Feed efficiency expressed as feed intake over body weight gain (g/g) was greater with the inclusion of the wheat-containing $64 \mathrm{mg} \mathrm{Zn/kg} \mathrm{DM}$ in the diet compared with the other wheat samples $(P=0.0001$, Fig. 1D). Interestingly, when supplemented with an extra $1.6 \mathrm{~g}$ ZnPic per kg diet, feed efficiency remained similar for the diet containing the wheat-containing $64 \mathrm{mg} \mathrm{Zn/kg} \mathrm{DM} \mathrm{(Fig.} \mathrm{1D).} \mathrm{Unlike} \mathrm{the} \mathrm{inclusion} \mathrm{of} \mathrm{the}$ wheat-containing $64 \mathrm{mg} \mathrm{Zn/kg} \mathrm{DM,} \mathrm{however,} \mathrm{supplement-}$ ing $\mathrm{ZnPic}$ to the diets containing the other $\mathrm{Zn}$-biofortified wheat samples with either 18 or $34 \mathrm{mg} \mathrm{Zn} / \mathrm{kg}$ DM equally increased the feed efficiency $(P=0.0001)$. Nevertheless, all ZnPic-supplemented groups of quails had similar feed efficiency.

Although the liver and heart weights of the quails were all similar among treatments $(P>0.05)$, cold carcass weights were greater with the inclusion of the wheat grains containing $64 \mathrm{mg} \mathrm{Zn/kg} \mathrm{DM}$ to the diet compared with the other wheat grains $(P=0.0001$, Fig. $1 \mathrm{E}-\mathrm{H})$, and supplementing $\mathrm{ZnPic}$ to each diet equally but further increased the cold carcass weights $(P=0.0001$, Fig. 1E). However, all ZnPic-supplemented groups of quails had similar cold carcass weights. Cold carcass yields were similar among the quail-fed diets containing different wheat samples with different $\mathrm{Zn}$ but no supplementation. However, supplementing ZnPic to each diet increased the cold carcass yields, particularly the diet with the wheat-containing $34 \mathrm{mg} \mathrm{Zn/kg} \mathrm{DM} \mathrm{(} P=0.001$; Fig. 1F).

Nitrogen, $\mathrm{Zn}$, and Fe retentions increased as the biofortified wheat samples had more $\mathrm{Zn}$ concentration $(P \leq 0.026$; Table 3). Interestingly, when supplemented with an extra $1.6 \mathrm{~g} \mathrm{ZnPic} \mathrm{per} \mathrm{kg}$ diet, the retentions remained similar for the diet containing the wheat sample with $64 \mathrm{mg} \mathrm{Zn/}$ $\mathrm{kg}$ DM. However, supplementing $\mathrm{ZnPic}$ to the diets containing other $\mathrm{Zn}$ biofortified wheat grains with either 18 or 
Fig. 1 Final body weight (A), body weight gain (B), cumulative feed intake $(\mathrm{C})$, feed efficiency: cumulative feed intake, g/body weight gain, $g$ (D), cold carcass weight (E), cold carcass yield $(\mathrm{F})$, liver weight $(\mathrm{G})$ and heart weight $(\mathrm{H})$ of quails fed different wheat varieties and supplemental organic Zn. Statistical comparisons are indicated with different superscript (a-c) located above the groups $(p<0.05 ; *$ ANOVA and Tukey's post-hoc test)
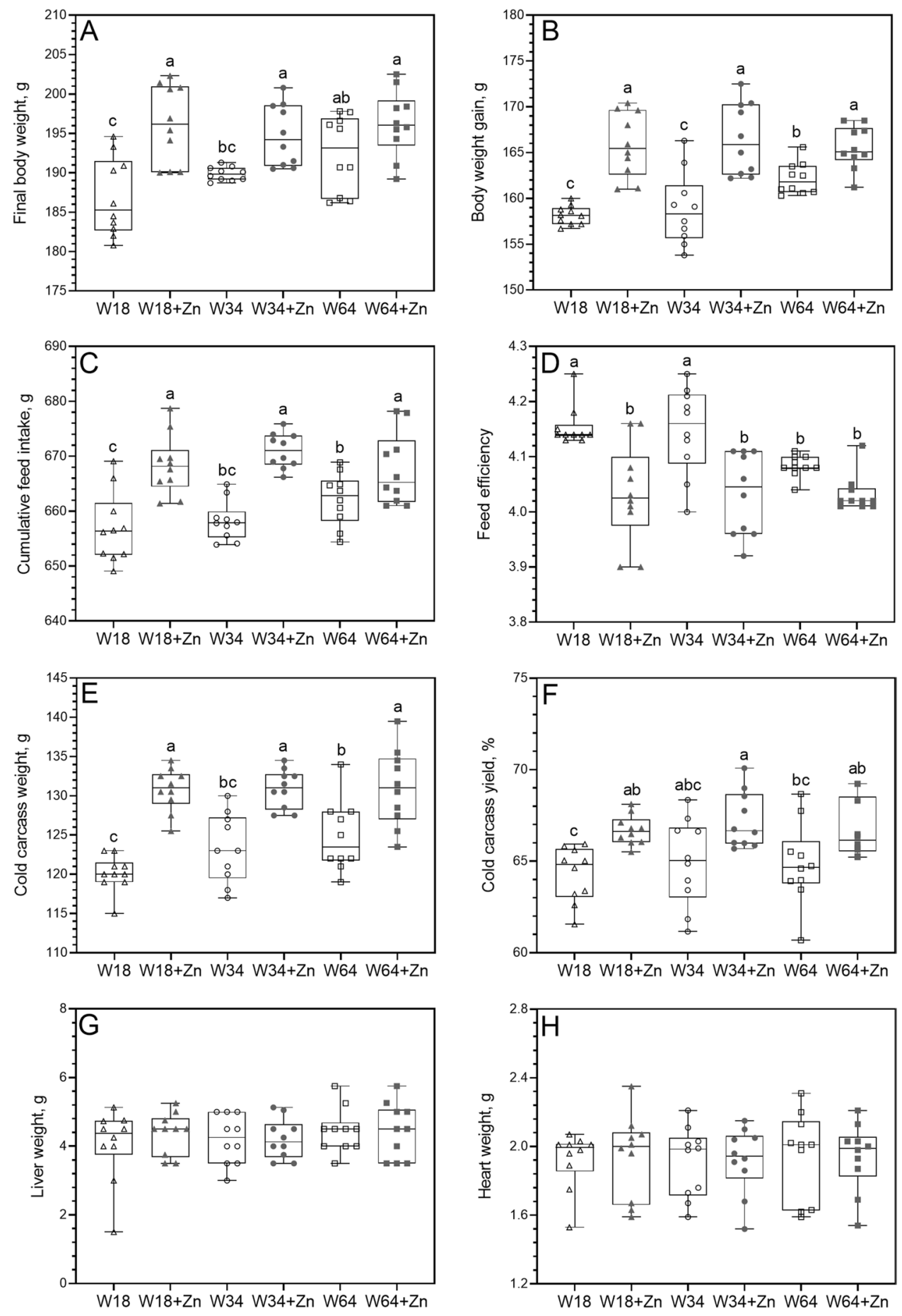

$34 \mathrm{mg} Z \mathrm{Zn} / \mathrm{kg}$ DM equally increased the retentions. Nevertheless, all ZnPic-supplemented groups of quails had similar nitrogen, $\mathrm{Zn}$, and Fe retentions. Ash and copper retentions changed similarly, such that inclusion of the $\mathrm{Zn}$ biofortified wheat grains containing $64 \mathrm{mg} \mathrm{Zn/kg} \mathrm{DM}$ to the diet compared with other wheat samples provided greater retentions $(P \leq 0.026$, Table 3$)$ which were not further increased with an extra $1.6 \mathrm{~g} \mathrm{ZnPic} \mathrm{per} \mathrm{kg}$ diet supplementation. Unlike the supplementation to the diet containing the wheat sample with $64 \mathrm{mg} \mathrm{Zn/kg} \mathrm{DM,} \mathrm{supplementing} \mathrm{ZnPic} \mathrm{to} \mathrm{the}$ diets containing the other wheat samples with either 18 or $34 \mathrm{mg} \mathrm{Zn/kg} \mathrm{DM}$ increased the retentions. Yet, ash and copper retentions remained similar in all ZnPic-supplemented groups of quails.

Calcium retention was greater with the inclusion of the wheat sample containing $64 \mathrm{mg} \mathrm{Zn/kg}$ to the diet compared with the other wheat grains with the lower amount of $\mathrm{Zn}$ $(P=0.003$, Table 3$)$, and supplementing $\mathrm{ZnPic}$ to each diet 
Table 3 Nutrient retention and excretion in quails fed different wheat varieties containing different zinc levels (dry matter basis)

\begin{tabular}{|c|c|c|c|c|c|c|}
\hline \multirow[t]{2}{*}{ Dietary component } & \multicolumn{6}{|l|}{ Treatments* } \\
\hline & W18 & $\mathrm{W} 18+\mathrm{Zn}$ & W34 & $\mathrm{W} 34+\mathrm{Zn}$ & W64 & $\mathrm{W} 64+\mathrm{Zn}$ \\
\hline \multicolumn{7}{|l|}{ Retention } \\
\hline Nitrogen, g/bird/d & $1.94 \pm 0.04^{\mathrm{c}}$ & $2.69 \pm 0.01^{\mathrm{a}}$ & $2.19 \pm 0.06^{\mathrm{b}}$ & $2.72 \pm 0.03^{\mathrm{a}}$ & $2.65 \pm 0.07^{\mathrm{a}}$ & $2.76 \pm 0.06^{\mathrm{a}} 0.012$ \\
\hline Ash, g/bird/d & $8.16 \pm 0.65^{\mathrm{b}}$ & $11.57 \pm 0.26^{\mathrm{a}}$ & $9.27 \pm 0.73^{b}$ & $11.12 \pm 0.33^{\mathrm{a}}$ & $11.69 \pm 0.57^{\mathrm{a}}$ & $11.63 \pm 0.69^{\mathrm{a}} 0.026$ \\
\hline Calcium, g/bird/d & $0.86 \pm 0.02^{\mathrm{c}}$ & $1.72 \pm 0.03^{\mathrm{ab}}$ & $0.96 \pm 0.06^{\mathrm{c}}$ & $1.51 \pm 0.07^{\mathrm{ab}}$ & $1.35 \pm 0.08^{\mathrm{b}}$ & $1.84 \pm 0.04^{\mathrm{a}} 0.003$ \\
\hline Phosphorus, g/bird/d & $0.23 \pm 0.01^{\mathrm{c}}$ & $0.57 \pm 0.02^{\mathrm{a}}$ & $0.34 \pm 0.01^{\mathrm{b}}$ & $0.55 \pm 0.02^{\mathrm{a}}$ & $0.39 \pm 0.01^{\mathrm{b}}$ & $0.59 \pm 0.02^{\mathrm{a}} 0.014$ \\
\hline Zinc, mg/bird/d & $10.49 \pm 1.14^{\mathrm{c}}$ & $58.52 \pm 4.26^{\mathrm{a}}$ & $23.58 \pm 2.03^{b}$ & $59.99 \pm 5.31^{\mathrm{a}}$ & $51.24 \pm 4.75^{\mathrm{a}}$ & $58.57 \pm 3.16^{\mathrm{a}} 0.0001$ \\
\hline Copper, mg/bird/d & $0.35 \pm 0.05^{\mathrm{b}}$ & $0.78 \pm 0.11^{\mathrm{a}}$ & $0.46 \pm 0.06^{\mathrm{b}}$ & $0.77 \pm 0.09^{\mathrm{a}}$ & $0.72 \pm 0.04^{\mathrm{a}}$ & $0.75 \pm 0.09^{\mathrm{a}} 0.002$ \\
\hline Iron, mg/bird/d & $1.36 \pm 0.23^{\mathrm{c}}$ & $3.74 \pm 0.22^{\mathrm{a}}$ & $2.22 \pm 0.14^{\mathrm{b}}$ & $3.76 \pm 0.23^{\mathrm{a}}$ & $3.52 \pm 0.17^{\mathrm{a}}$ & $3.73 \pm 0.15^{\mathrm{a}} 0.026$ \\
\hline \multicolumn{7}{|l|}{ Excretion } \\
\hline Nitrogen, g/bird/d & $1.63 \pm 0.02^{\mathrm{a}}$ & $1.31 \pm 0.03^{\mathrm{c}}$ & $1.46 \pm 0.02^{\mathrm{b}}$ & $1.36 \pm 0.01^{\mathrm{bc}}$ & $1.42 \pm 0.03^{\mathrm{b}}$ & $1.29 \pm 0.02^{\mathrm{c}} 0.001$ \\
\hline Ash, g/bird/d & $11.06 \pm 0.75^{\mathrm{a}}$ & $8.37 \pm 0.52^{c}$ & $9.31 \pm 0.63^{b}$ & $8.82 \pm 0.34^{\mathrm{c}}$ & $9.07 \pm 0.27^{b}$ & $8.41 \pm 0.39^{c} 0.002$ \\
\hline Calcium, g/bird/d & $0.81 \pm 0.03^{\mathrm{a}}$ & $0.63 \pm 0.02^{b}$ & $0.78 \pm 0.03^{\mathrm{a}}$ & $0.65 \pm 0.03^{b}$ & $0.73 \pm 0.03^{\mathrm{a}}$ & $0.66 \pm 0.02^{\mathrm{b}} 0.0001$ \\
\hline Phosphorus, g/bird/d & $0.67 \pm 0.12^{\mathrm{a}}$ & $0.30 \pm 0.06^{\mathrm{c}}$ & $0.39 \pm 0.09^{b}$ & $0.33 \pm 0.07^{c}$ & $0.35 \pm 0.06^{\mathrm{bc}}$ & $0.32 \pm 0.07^{\mathrm{c}} 0.023$ \\
\hline Zinc, mg/bird/d & $10.83 \pm 1.01^{\mathrm{a}}$ & $8.15 \pm 0.93^{c}$ & $9.46 \pm 0.67^{b}$ & $8.25 \pm 1.03^{c}$ & $8.96 \pm 1.07^{\mathrm{bc}}$ & $8.18 \pm 0.46^{\mathrm{c}} 0.0001$ \\
\hline Copper, mg/bird/d & $2.88 \pm 0.11^{\mathrm{a}}$ & $2.16 \pm 0.04^{\mathrm{c}}$ & $2.65 \pm 0.08^{b}$ & $2.19 \pm 0.23^{\mathrm{c}}$ & $2.23 \pm 0.17^{\mathrm{c}}$ & $2.26 \pm 0.12^{\mathrm{c}} 0.0001$ \\
\hline Iron, mg/bird/d & $38.43 \pm 2.41^{\mathrm{a}}$ & $32.21 \pm 3.34^{\mathrm{c}}$ & $34.721 \pm 2.62^{b}$ & $34.82 \pm 3.18^{\mathrm{b}}$ & $33.75 \pm 2.17^{b c}$ & $32,26 \pm 1.30^{\mathrm{c}}$ \\
\hline
\end{tabular}

*Dietary treatments are regular diets including either $18 \mathrm{mg} / \mathrm{kg} \mathrm{Zn-containing} \mathrm{wheat} \mathrm{along} \mathrm{with} \mathrm{no} \mathrm{ZnPic} \mathrm{supplemented} \mathrm{to} \mathrm{the} \mathrm{diet} \mathrm{(W18),}$ or $18 \mathrm{mg} / \mathrm{kg}$ Zn-containing wheat along with $212.4 \mathrm{mg} / \mathrm{kg} \mathrm{ZnPic} \mathrm{(44.6} \mathrm{elemental} \mathrm{Zn)} \mathrm{supplemented} \mathrm{to} \mathrm{the} \mathrm{diet} \mathrm{(W18+Zn),} \mathrm{or} 34 \mathrm{mg} / \mathrm{kg} \mathrm{Zn-}$ containing wheat along with no ZnPic supplemented to the diet (W34), or $34 \mathrm{mg} / \mathrm{kg} \mathrm{Zn}$-containing wheat along with $189.5 \mathrm{mg} / \mathrm{kg} \mathrm{ZnPic}$ (39.8 elemental Zn) supplemented to the diet (W34+Zn), or $64 \mathrm{mg} / \mathrm{kg}$ Zn-containing wheat along with no ZnPic supplemented to the diet (W64), or $64 \mathrm{mg} / \mathrm{kg}$ Zn-containing wheat along with $146.7 \mathrm{mg} / \mathrm{kg} \mathrm{ZnPic} \mathrm{(30.8} \mathrm{elemental} \mathrm{Zn)} \mathrm{supplemented} \mathrm{to} \mathrm{the} \mathrm{diet} \mathrm{(W64} \mathrm{+} \mathrm{Zn).} \mathrm{Statistical} \mathrm{comparisons}$ are indicated with different superscript $(\mathrm{a}-\mathrm{c})$ in the same row $(P<0.05 ; *$ ANOVA and Tukey's post hoc test). Mean values are demonstrated with \pm standard error of mean

increased the retention, particularly with the diet having wheat samples with $64 \mathrm{mg} \mathrm{Zn/kg} \mathrm{DM,} \mathrm{providing} \mathrm{the} \mathrm{greatest}$ $\mathrm{Ca}$ retention. The diets containing the wheat samples with 34 and $64 \mathrm{mg} \mathrm{Zn/kg} \mathrm{DM} \mathrm{yielded} \mathrm{greater} \mathrm{phosphorous} \mathrm{reten-}$ tion compared with the diet containing the wheat grain with $18 \mathrm{mg} \mathrm{Zn/kg}(P=0.014)$. However, supplementing ZnPic to each diet equally increased the $P$ retentions bringing the values to similar ranges.

Excretion of nitrogen and ash was lower for the diets, including the biofortified wheat grains with 34 and $64 \mathrm{mg}$ $\mathrm{Zn} / \mathrm{kg}$ DM compared with wheat grains with $18 \mathrm{mg} \mathrm{Zn/kg}$ DM $(P=0.002$, Table 3$)$. The excretions equally decreased even more, when additional ZnPic was supplemented to each diet containing different wheat samples. Calcium excretion remained similar among diets containing different wheat samples having 18, 34, or $64 \mathrm{mg} \mathrm{Zn/kg} \mathrm{DM}$ $(P=0.0001)$. However, supplementing $\mathrm{ZnPic}$ to each diet equally decreased $\mathrm{Ca}$ excretions. Inclusion of the wheat samples containing either 34 or $64 \mathrm{mg} \mathrm{Zn/kg} \mathrm{DM} \mathrm{decreased} \mathrm{the}$ $\mathrm{P}$ excretion $(P=0.023)$, but supplementing $\mathrm{ZnPic}$ to all diets containing all wheat samples further but equally decreased the $\mathrm{P}$ excretion.

Inclusion of wheat varieties with increasing $\mathrm{Zn}$ concentration in the diet resulted in decreases in $\mathrm{Zn}$ and $\mathrm{Cu}$ excretion $(P=0.0001$, Table 3$)$, and supplementing $\mathrm{ZnPic}$ to each diet equally but further decreased $\mathrm{Zn}$ and $\mathrm{Cu}$ excretions, except for $\mathrm{Cu}$ excretion with the diet containing the wheat with $64 \mathrm{mg} \mathrm{Zn/kg} \mathrm{DM} \mathrm{which} \mathrm{remained} \mathrm{unchanged} \mathrm{when}$ $\mathrm{ZnPic}$ was supplemented. Excretion of iron was lower for the diets, including the wheat samples with 34 and $64 \mathrm{mg}$ $\mathrm{Zn} / \mathrm{kg}$ DM compared with that of wheat with $18 \mathrm{mg} \mathrm{Zn/kg}$ $(P=0.001)$. The excretions were even lower when additional ZnPic was supplemented to the diets, including 18 or $64 \mathrm{mg} /$ $\mathrm{kg} \mathrm{Zn-containing} \mathrm{wheat} \mathrm{samples} \mathrm{compared} \mathrm{with} \mathrm{the} 34 \mathrm{mg} /$ $\mathrm{kg}$ Zn-containing wheat.

Changes in serum and tissue $\mathrm{Zn}, \mathrm{Cu}$, and $\mathrm{Fe}$ concentrations upon feeding different $\mathrm{Zn}$ biofortifiedwheat samples and dietary ZnPic supplementation are shown in Fig. 2 and Table 4. Serum Zn concentrations equally increased when the wheat sample with $18 \mathrm{mg}$ $\mathrm{Zn} / \mathrm{kg} \mathrm{DM}$ was replaced with the other wheat samples in the diet and with supplementation of $\mathrm{ZnPic}$ in each diet ( $P=0.002$, Fig. 2A). Liver and heart $\mathrm{Zn}$ concentrations increased with increasing $\mathrm{Zn}$ concentration of wheat samples $(P=0.001$, Fig. $2 \mathrm{~B}-\mathrm{C})$. The liver $\mathrm{Zn}$ concentrations further increased with each dietary supplementation of $\mathrm{ZnPic}$. Although $\mathrm{ZnPic}$ supplementation resulted in further but equal increases in heart tissue, $\mathrm{Zn}$ concentrations of quails fed a diet containing the wheat samples with 18 and $34 \mathrm{mg} \mathrm{Zn} / \mathrm{kg}$ DM compared with 
Fig. 2 Zn levels of serum (A), liver (B), hearth (C), and tight meat (D) in quails fed different wheat varieties and supplemental organic Zn. Statistical comparisons are indicated with different superscript $(\mathrm{a}-\mathrm{e})$ located above the groups $(P<0.05$; ANOVA and Tukey's post hoc test)
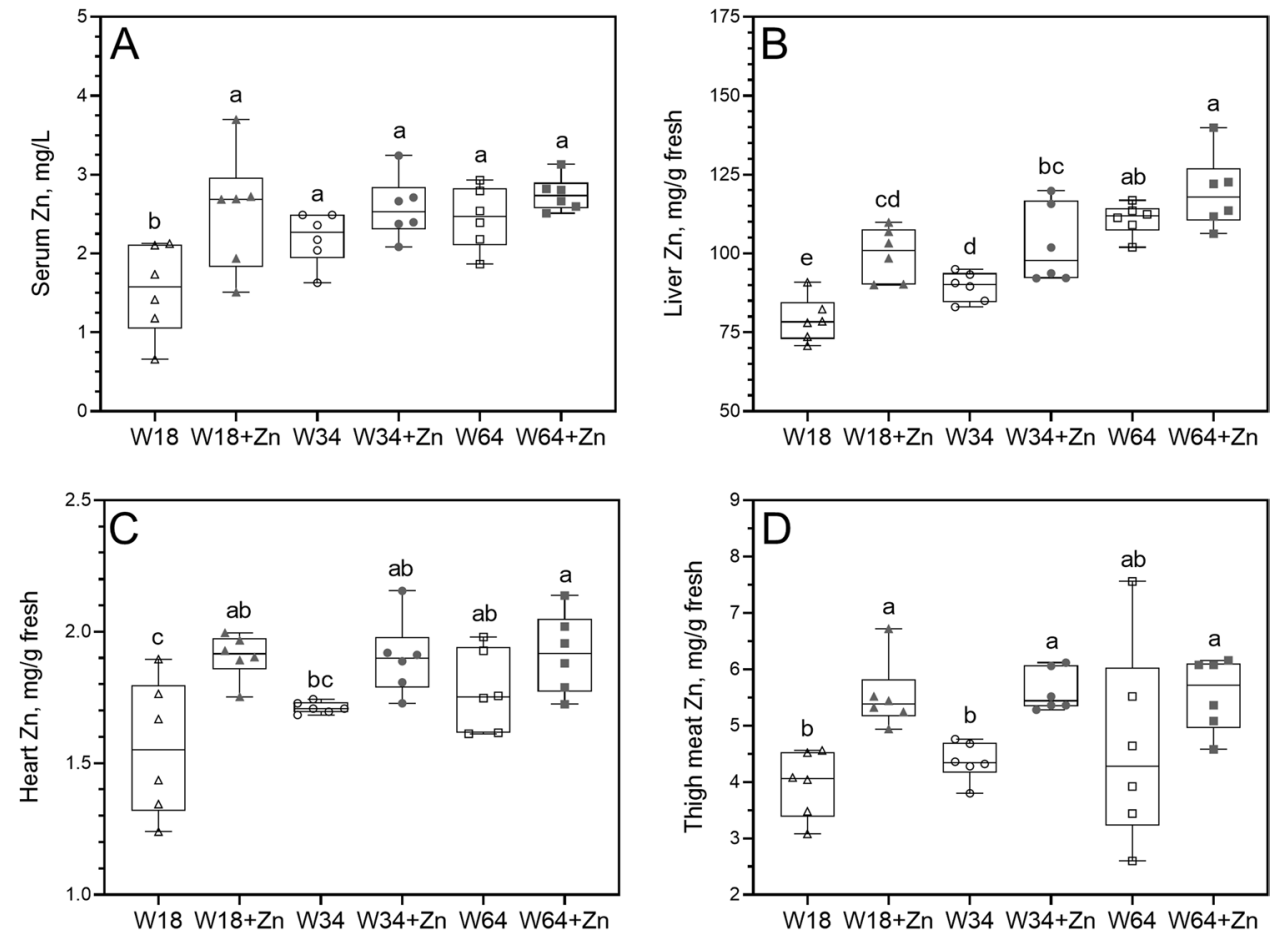

Table 4 Copper and iron concentrations of serum and various tissues from quails fed different wheat varieties containing different zinc levels

\begin{tabular}{|c|c|c|c|c|c|c|c|}
\hline & \multicolumn{6}{|l|}{ Treatments* } & \multirow[t]{2}{*}{$-P-$} \\
\hline & W18 & $\mathrm{W} 18+\mathrm{Zn}$ & W34 & $\mathrm{W} 34+\mathrm{Zn}$ & W64 & $\mathrm{W} 64+\mathrm{Zn}$ & \\
\hline \multicolumn{8}{|l|}{ Copper } \\
\hline Serum, mg/L & $0.141 \pm 0.014$ & $0.128 \pm 0.010$ & $0.129 \pm 0.18$ & $0.110 \pm 0.13$ & $0.117 \pm 0.015$ & $0.106 \pm 0.016$ & $>0.05$ \\
\hline Liver, mg/g fresh & $13.77 \pm 1.10^{\mathrm{a}}$ & $11.44 \pm 0.44^{\mathrm{b}}$ & $14.63 \pm 1.20^{\mathrm{a}}$ & $11.13 \pm 0.60^{\mathrm{b}}$ & $11.14 \pm 0.41^{\mathrm{b}}$ & $10.68 \pm 0.52^{\mathrm{b}}$ & 0.004 \\
\hline Heart, mg/g fresh & $0.136 \pm 0.009^{\mathrm{a}}$ & $0.118 \pm 0.004^{\mathrm{a}}$ & $0.131 \pm 0.006^{\mathrm{a}}$ & $0.108 \pm 0.016^{\mathrm{ab}}$ & $0.115 \pm 0.007^{\mathrm{ab}}$ & $0.089 \pm 0.007^{\mathrm{b}}$ & 0.014 \\
\hline $\begin{array}{l}\text { Thigh meat, } \mathrm{mg} / \mathrm{g} \text { fresh } \\
\text { Iron }\end{array}$ & $0.125 \pm 0.004$ & $0.117 \pm 0.003$ & $0.125 \pm 0.002$ & $0.121 \pm 0.005$ & $0.127 \pm 0.001$ & $0.120 \pm 0.002$ & $>0.05$ \\
\hline Serum, mg/L & $5.56 \pm 0.71$ & $4.05 \pm 0.28$ & $4.13 \pm 0.30$ & $4.72 \pm 0.15$ & $5.51 \pm 0.72$ & $6.50 \pm 1.51$ & $>0.05$ \\
\hline Liver, $\mathrm{mg} / \mathrm{g}$ fresh & $118.25 \pm 8.61^{\mathrm{c}}$ & $144.33 \pm 13.39^{\mathrm{ab}}$ & $126.14 \pm 3.52^{\mathrm{bc}}$ & $142.47 \pm 7.82^{\mathrm{abc}}$ & $141.97 \pm 4.18^{\mathrm{abc}}$ & $159.51 \pm 6.02^{\mathrm{a}}$ & 0.016 \\
\hline Heart, mg/g fresh & $7.14 \pm 0.32$ & $6.74 \pm 0.23$ & $7.45 \pm 0.48$ & $7.00 \pm 0.21$ & $6.29 \pm 0.18$ & $7.11 \pm 0.45$ & $>0.05$ \\
\hline Thigh meat, $\mathrm{mg} / \mathrm{g}$ fresh & $1.62 \pm 0.11^{\mathrm{c}}$ & $2.42 \pm 0.34^{\mathrm{ab}}$ & $1.92 \pm 0.14^{\mathrm{bc}}$ & $2.80 \pm 0.22^{\mathrm{a}}$ & $2.16 \pm 0.08^{\mathrm{bc}}$ & $2.83 \pm 0.09^{\mathrm{a}}$ & 0.0001 \\
\hline
\end{tabular}

*Dietary treatments are regular diets including either $18 \mathrm{mg} / \mathrm{kg} \mathrm{Zn-containing} \mathrm{wheat} \mathrm{along} \mathrm{with} \mathrm{no} \mathrm{ZnPic} \mathrm{supplemented} \mathrm{to} \mathrm{the} \mathrm{diet} \mathrm{(W18),}$ or $18 \mathrm{mg} / \mathrm{kg} \mathrm{Zn-containing} \mathrm{wheat} \mathrm{along} \mathrm{with} 212.4 \mathrm{mg} / \mathrm{kg} \mathrm{ZnPic} \mathrm{(44.6} \mathrm{elemental} \mathrm{Zn)} \mathrm{supplemented} \mathrm{to} \mathrm{the} \mathrm{diet} \mathrm{(W18+Zn),} \mathrm{or} 34 \mathrm{mg} / \mathrm{kg} \mathrm{Zn-}$ containing wheat along with no ZnPic supplemented to the diet (W34), or $34 \mathrm{mg} / \mathrm{kg} \mathrm{Zn-containing} \mathrm{wheat} \mathrm{along} \mathrm{with} 189.5 \mathrm{mg} / \mathrm{kg} \mathrm{ZnPic} \mathrm{(39.8}$ elemental Zn) supplemented to the diet (W34+Zn), or $64 \mathrm{mg} / \mathrm{kg}$ Zn-containing wheat along with no ZnPic supplemented to the diet (W64), or $64 \mathrm{mg} / \mathrm{kg}$ Zn-containing wheat along with $146.7 \mathrm{mg} / \mathrm{kg}$ ZnPic (30.8 elemental Zn) supplemented to the diet (W64 + Zn). Statistical comparisons are indicated with different superscript $(\mathrm{a}-\mathrm{c})$ in the same row $(P<0.05 ; *$ ANOVA and Tukey's post hoc test). Mean values are demonstrated with \pm standard error of mean

non-supplemental groups, supplementing ZnPic to the diet containing the wheat with $64 \mathrm{mg} \mathrm{Zn} / \mathrm{kg}$, had the greatest heart $\mathrm{Zn}$ concentrations. Thigh meat Zn concentrations increased, although not statistically significant, with increasing $\mathrm{Zn}$ concentration of the wheat samples. However, supplementing ZnPic to each diet equally increased the thigh meat $\mathrm{Zn}$ concentrations $(P=0.006$,
Fig. 2D), bringing the values to similar ranges within supplemented groups.

Serum and thigh meat $\mathrm{Cu}$ concentrations remained unchanged among treatments $(P>0.05$, Table 4$)$. The liver $\mathrm{Cu}$ concentrations decreased only with feeding the wheatcontaining $64 \mathrm{mg} \mathrm{Zn/kg} \mathrm{DM}(P=0.004)$, the measured level of which was similar for all supplemental treatments. Inclusion of wheat samples with different $\mathrm{Zn}$ concentrations to 
the diets fed to quails decreased, although not significantly, the heart $\mathrm{Cu}$ concentrations. Supplementing $\mathrm{ZnPic}$ to the diets, particularly the wheat with the highest $\mathrm{Zn}$, further reduced the heart $\mathrm{Cu}$ concentrations $(P=0.014)$.

Serum and heart $\mathrm{Fe}$ concentrations remained similar among treatments $(P>0.05$, Table 4$)$. Although not significantly, increasing $\mathrm{Zn}$ concentrations in the wheat grains resulted in increases in liver Fe concentrations. In addition, further increases with $\mathrm{ZnPic}$ supplementations were observed in liver Fe concentrations, particularly with ZnPicsupplemented wheat samples containing $64 \mathrm{mg} \mathrm{Zn/kg} \mathrm{DM}$ as being greatest $(P=0.016)$. Thigh meat Fe concentrations increased with increasing $\mathrm{Zn}$ concentrations of the wheat $(P=0.0001)$. Further increases were observed with $\mathrm{ZnPic}$ supplementations to the diets, particularly with the diets containing wheat with 34 and $64 \mathrm{mg} \mathrm{Zn} / \mathrm{kg}(P=0.0001)$.

\section{Discussion}

Biofortification of food and feed crops with micronutrients is a growing interest and acceptance with particular positive effects. In a recent study, enrichment of silage maize with $\mathrm{Zn}, \mathrm{Se}$, and $\mathrm{Fe}$ by using fertilizers (i.e., agronomic biofortification) has been shown as a useful strategy to improve the micronutrient nutrition of animals [26]. The present study also showed that wheat enriched with $\mathrm{Zn}$ using agronomic biofortification is a highly useful strategy to improve animal feedstuffs with $\mathrm{Zn}$.

Live performance, measured as body weight gains, feed intake, and feed efficiency, were greater when the quails were fed a diet containing wheat with $64 \mathrm{mg} \mathrm{Zn/kg} \mathrm{DM.}$ Supplementing proper amounts of $\mathrm{ZnPic}$ to balance the required $\mathrm{Zn}$ levels in each diet provided similar live performances. Therefore, the inclusion of the $\mathrm{Zn}$-biofortified wheat-containing $64 \mathrm{mg} \mathrm{Zn/kg} \mathrm{DM}$ in the diet itself provides better performance, compared with those of other wheat samples, without any additional $\mathrm{Zn}$ sources. Similar results were also obtained from the cold carcass weights of the present work.

Deficiency of $\mathrm{Zn}$ in diets containing the wheat samples biofortified with lower levels of Zn (i.e., either 18 or $34 \mathrm{mg}$ $\mathrm{Zn} / \mathrm{kg} \mathrm{DM}$ ) without supplementation resulted in a slowed growth (less weight gain) and feed efficiency as compared with the wheat samples biofortified with $\mathrm{Zn}$ at the highest level (i.e., $64 \mathrm{mg} \mathrm{Zn/kg} \mathrm{DM)} \mathrm{at} \mathrm{the} \mathrm{present} \mathrm{work.} \mathrm{The}$ wheat samples containing $64 \mathrm{mg} \mathrm{Zn/kg} \mathrm{DM}$ were close to the required level, thus providing the greatest live performance in quails. Retardation in growth and development as a result of $\mathrm{Zn}$ deficiency has been well-documented in poultry [27]. In ducks fed a $\mathrm{Zn}$-deficient diet, significant decreases were found in growth, reproductive performance, and plasma antioxidant pool [28]. Zinc supplementation has also been proved to support chick growth, immune system, and feathering along with accelerating live performance and digestibility in poultry $[4,9,10,14]$. However, contrary to the present work results, Yogesh et al. [29] reported no differences in growth parameters in broiler chicks fed a diet containing various $\mathrm{Zn}$ levels from 40 to $100 \mathrm{mg} / \mathrm{kg}$ DM. Similarly, the $\mathrm{Zn}$ level above $40 \mathrm{mg} / \mathrm{kg}$ DM has been shown not to influence the performance of broiler chicks [30, 31].

As far as carcass performance was concerned, the results from the present work were in agreement with the results from Yogesh et al. [29] and Rossi et al. [32], who reported unchanged carcass characteristics in chicks fed a diet with increasing $\mathrm{Zn}$ concentrations. Similarly, increasing the $\mathrm{Zn}$ supplement to the diet of Pekin ducks caused no changes in dressing percentages [33]. However, increases in carcass yields have been observed in broiler chicks fed a diet supplemented with either Zn-sulfate or Zn-methionine at $80 \mathrm{mg} / \mathrm{kg}$ DM [34]. The differences in growth conditions, the composition of feeding diets, and the amount and form of $\mathrm{Zn}$ added are probably responsible for such controversial results. For example, Olukosi et al. [35] showed that Zn hydroxychloride, compared with those of $\mathrm{Zn}$ sulfate, had better effects on growth parameters and meat yield in broiler chickens. In a further study, Olukosi et al. [36] found that using hydroxychloride trace minerals such as $\mathrm{Zn}, \mathrm{Cu}$, and $\mathrm{Mn}$, compared with those of sulfate salts, in the diet of broilers and laying hens provided a better growth performance, reducing egg loss along with alleviated oxidative stress. Hydroxychloride trace minerals are released slowly due to their crystalline structure during digestion, resulting in better absorption and decreased excretion [37]. Similarly, Ao et al. [38] measured greater growth rates and bone $\mathrm{Zn}$ accumulation in broiler chicks fed a diet supplemented with organic $\mathrm{Zn}$ ( $\mathrm{Zn}$ proteinate), as compared with inorganic $\mathrm{Zn}\left(\mathrm{ZnSO}_{4}\right)$. The supplemental $\mathrm{Zn}$ sources as $\mathrm{ZnPic}$ of the present work were used to minimize the interaction among other minerals and better bioavailability.

Improved digestibility of all nutrients (nitrogen, $\mathrm{Ca}$, $\mathrm{P}, \mathrm{Zn}, \mathrm{Cu}$, and $\mathrm{Fe}$ ), measured as increased retentions and decreased excretions, were observed in quails fed a diet containing the wheat samples, particularly with $64 \mathrm{mg} \mathrm{Zn/}$ $\mathrm{kg}$ DM. Increased live performance of quails fed a diet with the wheat samples of $64 \mathrm{mg} \mathrm{Zn} / \mathrm{kg}^{-1} \mathrm{DM}$ was supported by the improved digestibility of the nutrients from the present work. However, contrary to the current work results, Yogesh et al. [29] found decreased $\mathrm{Zn}$ retentions with increasing Zn levels from 40 to $100 \mathrm{mg} / \mathrm{kg} \mathrm{DM}$ in a diet fed to broiler chicks. Similarly, chicks were reported to excrete more $\mathrm{Zn}$ when the diet contained increasing $\mathrm{Zn}$ levels up to $178 \mathrm{mg} / \mathrm{kg}$ DM [39]. However, broiler chicks fed a diet supplemented with organic $\mathrm{Zn}$ (Zn-amino acid) compared with zinc sulfate up to $80 \mathrm{mg} / \mathrm{kg}$ DM were observed to excrete less $\mathrm{Zn}$ [40]. 
Increasing the $\mathrm{Zn}$ concentration of the wheat samples resulted in increases, as expected, in serum and tissue $\mathrm{Zn}$ concentrations at the present work. These results were also in agreement with the retention of $\mathrm{Zn}$ with increasing $\mathrm{Zn}$ concentration of the wheat samples. Increased tissue concentrations of $\mathrm{Zn}$ would be desirable in combating $\mathrm{Zn}$ deficiency upon consumption of these tissues by humans. The same is also true for consuming the wheat samples themselves containing $64 \mathrm{mg} \mathrm{Zn/kg} \mathrm{DM.} \mathrm{Therefore,} \mathrm{consuming} \mathrm{either} \mathrm{the}$ wheat samples containing greater $\mathrm{Zn}$ concentration or the tissues (meat or organs) from the animals fed the same wheat samples offers a two-sided benefit. Similar to the present work results, supplemental organic or inorganic $\mathrm{Zn}$ sources to the diet of broiler chicks, laying hens, and Pekin ducks have been reported to increase blood and liver $\mathrm{Zn}$ concentrations [10, 14, 33]. Liver $\mathrm{Zn}$ concentrations are considered an important indicator of the whole-body level [41].

Since $\mathrm{Zn}$ is also involved in bone calcification in broilers, [42] increased $\mathrm{Zn}$ concentration in the diet was expected to increase $\mathrm{Ca}$ and $\mathrm{P}$ retentions, as evidenced in the present study. Although bone calcification was not measured at the current work, the increased levels of $\mathrm{Zn}$ in the diet have been reported to increase $\mathrm{Zn}$ and $\mathrm{Ca}$ concentrations in the tibia of laying hens [43], broiler chicks [34], and Pekin ducks [33].

Increasing the $\mathrm{Zn}$ concentration of the wheat samples also resulted in increases in liver and thigh Fe concentrations but decreases in liver and heart $\mathrm{Cu}$ concentrations at the present work. As opposed to the current study results, supplementing either organic or inorganic $\mathrm{Zn}$ to the diet of laying hens was found not to influence the blood $\mathrm{Cu}$ or Fe concentrations [10]. However, the antagonist features of $\mathrm{Zn}$ and $\mathrm{Cu}$, as shown in the present work, were also found by Ognik et al. [44], who observed decreased $\mathrm{Zn}$ absorption from the intestines of chicks after $\mathrm{Cu}$ administrations with no effects on Fe absorption. Similar to the present work results, Olukosi et al. [35] also found that increasing $\mathrm{Zn}$ level in the diet of broiler chicks caused increases in plasma $\mathrm{Zn}$ but not in plasma $\mathrm{Cu}$ concentrations with no respect to $\mathrm{Zn}$ sources (sulfate or hydroxychloride) supplemented in the diet. However, in the same study [35], the liver $\mathrm{Cu}$ levels were greater with the inclusion of hydroxychloride $\mathrm{Zn}$ sources as compared to that of sulfate into the diet, independent from the $\mathrm{Zn}$ levels of the diet.

Although antagonistic features of $\mathrm{Zn}, \mathrm{Fe}$, and $\mathrm{Cu}$ have been known in chicks [45], the present work proved that the natural source of $\mathrm{Zn}$ in wheat does not interfere with $\mathrm{Fe}$ absorption or retention. Ao and Pierce [3] also indicated that the $\mathrm{Zn}, \mathrm{Fe}$, and $\mathrm{Cu}$ antagonisms could be avoided by supplementing organic $\mathrm{Zn}$ sources instead of inorganic ones in the poultry diet. Therefore, feeding the different wheat samples containing greater $\mathrm{Zn}$ concentration, particularly $64 \mathrm{mg} \mathrm{Zn/}$ $\mathrm{kg} \mathrm{DM}$, to quails increased both $\mathrm{Zn}$ and Fe concentrations of the animal tissues (meat and organs), which upon consumption offer health benefits to humans.

In general, supplementing $\mathrm{ZnPic}$ to balance the total $\mathrm{Zn}$ concentrations of the diets provided similar effects in responses to measured parameters at the present work. The main effect detected for the most measured parameters was the wheat samples, particularly one containing $64 \mathrm{mg} \mathrm{Zn/kg}$ $\mathrm{DM}$. The bioavailability of $\mathrm{Zn}$ in wheat samples was made possible through enzyme inclusions in the diets.

Wheat as a palatable feed for poultry can be included in poultry diets up to $60 \%$ or more along with soybean meal. Wheat has about 94-96\% of corn's energy but greater protein, lysine, and tryptophan compared with those of corn [46]. Therefore, wheat is a good replacement for corn in the poultry diet due to its availability and low cost. This is also true for the wheat samples containing greater $\mathrm{Zn}$ concentrations. Although balanced and made ideal for human consumption, raising the $\mathrm{Zn}$ concentration of the wheat samples further, through biofortification, up to $50 \mathrm{mg} / \mathrm{kg} \mathrm{DM}$ at the required level for the quail diets without compromising the balance of other nutrients needs be elucidated. Wheat, mostly used for human consumption, may not be appropriate for feeding animals due to its hardness and probably its starch type and concentration influencing the foregut digestibility of poultry, besides the cost issue. However, because of enzyme addition to the diet and limited inclusion (30\%) of the wheat in the diet, these issues seem not a problem for feeding quails as evidenced at the present work, providing better performance, greater digestibility, and elevated serum and tissue $\mathrm{Zn}$ and $\mathrm{Fe}$ concentrations particularly with the wheat samples containing $64 \mathrm{mg} \mathrm{Zn/kg} \mathrm{DM.} \mathrm{Although} \mathrm{not}$ meant to be designed particularly for animal consumption, the wheat samples with $64 \mathrm{mg} \mathrm{Zn/kg} \mathrm{DM} \mathrm{are} \mathrm{also} \mathrm{a} \mathrm{good}$ choice as an animal feed, particularly for poultry.

Author Contribution Conceptualization, K.S. and I.C.; data curation, N.S. and C.O., methodology, N.S., O.K., C.O., and I.C.; formal analysis, N.S., E.S., C.O., K.S., and I.C.; writing-original draft preparation, O.K. and K.S.; and writing-review and editing, K.S. and I.C. The authors read and approved the final manuscript.

Funding This work was supported by the Turkish Academy of Sciences partly (KS).

Data Availability The datasets analyzed in the current study are available from the corresponding author on reasonable request.

Code Availability Not applicable.

\section{Declarations}

Ethics Approvals The experiment was conducted in accordance with animal welfare regulations at the Veterinary Control and Research Institute of Elazig, Turkey. 
Consent to Participate All participants provided written informed consent before participating in the study.

Conflict of Interest The authors declare no competing interests.

\section{References}

1. Park SY, Birkhold SG, Kubena LF, Nisbet DJ, Ricke SC (2004) Review on the role of dietary zinc in poultry nutrition, immunity, and reproduction. Biol Trace Elem Res 101(2):147-163. https:// doi.org/10.1385/BTER:101:2:147

2. Suttle NF (2010) Mineral nutrition of livestock, 4th edn. CABI, Cambridge

3. Ao T, Pierce $\mathbf{J}$ (2013) The replacement of inorganic mineral salts with mineral proteinates in poultry diets. Worlds Poult Sci J 69(1):5-16. https://doi.org/10.1017/S0043933913000019

4. Huang L, Li X, Wang W, Yang L, Zhu Y (2019) The role of zinc in poultry breeder and hen nutrition: an update. Biol Trace Elem Res 192(2):308-318. https://doi.org/10.1007/s12011-019-1659-0

5. Read SA, Obeid S, Ahlenstiel C, Ahlenstiel G (2019) The role of zinc in antiviral 1mmunity. Adv Nutr 10(4):696-710. https://doi. org/10.1093/advances/nmz013

6. Krężel A, Maret W (2016) The biological inorganic chemistry of zinc ions. Arch Biochem Biophys 611:3-19. https://doi.org/10. 1016/j.abb.2016.04.010

7. Huang YL, Lu L, Luo XG, Liu B (2007) An optimal dietary zinc level of broiler chicks fed a corn-soybean meal diet. Poult Sci 86:2582-2589. https://doi.org/10.3382/ps.2007-00088

8. Linares LB, Broomhead JN, Guaiume EA, Ledoux DR, Veum TL, Raboy V (2007) Effects of low phytate barley (Hordeum vulgare L.) on zinc utilization in young broiler chicks. Poult Sci 86(12):299-308

9. Huang YL, Lu L, Li SF, Luo XG, Liu B (2009) Relative bioavailabilities of organic zinc sources with different chelation strengths for broilers fed a conventional corn-soybean meal diet. J Anim Sci 87(6):2038-2046. https://doi.org/10.2527/jas.2008-1212

10. Abedini M, Shariatmadari F, Karimi Torshizi MA, Ahmadi H (2018) Effects of zinc oxide nanoparticles on the egg quality, immune response, zinc retention, and blood parameters of laying hens in the late phase of production. J Anim Physiol Anim Nutr (Berl) 102(3):736-745. https://doi.org/10.1111/jpn.12871

11. Gibson RS (2007) The role of diet- and host-related factors in nutrient bioavailability and thus in nutrient-based dietary requirement estimates. Food Nutr Bull 28(1 Suppl International):S77-100. https://doi.org/10.1177/1564826507 0281S 108

12. Cakmak I, Kutman UB (2018) Agronomic biofortification of cereals with zinc: a review. Eur J Soil Sci 69(1):172-180. https://doi. org/10.1111/ejss.12437

13. Welch RM, Graham RD (2004) Breeding for micronutrients in staple food crops from a human nutrition perspective. J Exp Bot 55:353-364. https://doi.org/10.1093/jxb/erh064

14. Ao T, Pierce JL, Pescatore AJ, Cantor AH, Dawson KA, Ford MJ, Paul M (2011) Effects of feeding different concentration and forms of zinc on the performance and tissue mineral status of broiler chicks. Br Poult Sci 52(4):466-471. https://doi.org/10. 1080/00071668.2011.588198

15. Naz S, Idris M, Khalique MA, Zia-Ur-Rahman AIA, Abdelrahman MM, Khan RU, Chand N, Farooq U, Ahmad S (2016) The activity and use of zinc in poultry diets. Worlds Poult Sci J 72(1):159-167. https://doi.org/10.1017/S0043933915002755
16. Cakmak I (2008) Enrichment of cereal grains with zinc: agronomic or genetic biofortification? Plant Soil 302(1-2):1-17. https://doi.org/10.1007/s11104-007-9466-3

17. Graham RD, Welch RM, Bouis HE (2001) Addressing micronutrient malnutrition through enhancing the nutritional quality of staple foods: principles, perspectives and knowledge gaps. Adv Agron 70:77-142. https://doi.org/10.1016/S0065-2113(01) 70004-1

18. Hill GM, Shannon MC (2019) Copper and zinc nutritional 1ssues for agricultural animal production. Biol Trace Elem Res 188(1):148-159. https://doi.org/10.1007/s12011-018-1578-5

19. Zou C, Du Y, Rashid A, Ram H, Savasli E, Pieterse PJ, OrtizMonasterio I, Yazici A, Kaur C, Mahmood K, Singh S, Le Roux MR, Kuang W, Onder O, Kalayci M, Cakmak I (2019) Simultaneous biofortification of wheat with zinc, iodine, selenium, and iron through foliar treatment of a micronutrient cocktail in six countries. J Agric Food Chem 67(29):8096-8106. https://doi.org/ 10.1021/acs.jafc.9b01829

20. Garg M, Sharma N, Sharma S, Kapoor P, Kumar A, Chunduri V, Arora P (2018) Biofortified crops generated by breeding, agronomy, and transgenic approaches are improving lives of millions of people around the world. Front Nutr 5:12. https://doi.org/10. 3389/fnut.2018.00012

21. Cakmak I, Kalayci M, Kaya Y, Torun AA, Aydin N, Wang Y, Arisoy Z, Erdem H, Yazici A, Gokmen O, Ozturk L, Horst WJ (2010) Biofortification and localization of zinc in wheat grain. J Agric Food Chem 58(16):9092-9102. https://doi.org/10.1021/ jf101197h

22. Signorell C, Zimmermann MB, Cakmak I, Wegmüller R, Zeder C, Hurrell R, Aciksoz SB, Boy E, Tay F, Frossard E, Moretti D (2019) Zinc absorption from agronomically biofortified wheat is similar to post-harvest fortified wheat and is a substantial source of bioavailable zinc in humans. J Nutr 149(5):840-846. https:// doi.org/10.1093/jn/nxy328

23. Joy EJM, Ahmad W, Zia MH, Kumssa DB, Young SD, Ander EL, Watts MJ, Stein AJ, Broadley MR (2017) Valuing increased zinc (Zn) fertiliser-use in Pakistan. Plant Soil 411(1):139-150. https:// doi.org/10.1007/s11104-016-2961-7

24. Council NR (1994) Nutrient requirements of poultry, 9th revise. The National Academies Press, Washington, DC

25. A.O.A.C. (1990) Official Methods of Analysis. 15th Edition, Association of Official Analytical Chemist, Washington DC

26. Grujcic D, Yazici AM, Tutus Y, Cakmak I, Singh BR (2021) Biofortification of silage maize with zinc, iron and selenium as affected by nitrogen fertilization. Plants 10(2):1-13. https://doi. org/10.3390/plants10020391

27. Salim HM, Jo C, Lee BD (2008) Zinc in broiler feeding and nutrition. Avian Biol Res 1(1):5-18. https://doi.org/10.3184/17581 5508X334578

28. Zhang YN, Wang S, Li KC, Ruan D, Chen W, Xia WG, Wang SL, Abouelezz KFM, Zheng CT (2020) Estimation of dietary zinc requirement for laying duck breeders: effects on productive and reproductive performance, egg quality, tibial characteristics, plasma biochemical and antioxidant indices, and zinc deposition. Poult Sci 99(1):454-462. https://doi.org/10.3382/ps/pez530

29. Yogesh K, Deo C, Shrivastava HP, Mandal AB, Wadhwa A, Singh I (2013) Growth performance, carcass yield, and immune competence of broiler chickens as influenced by dietary supplemental zinc sources and levels. Agric Res 2(3):270-274. https://doi.org/ 10.1007/s40003-013-0067-5

30. Mohanna G, Nys Y (1999) Effect of dietary zinc content and sources on the growth, body zinc deposition and retention, zinc excretion and immune response in chickens. Br Poult Sci 40(1):108-114. https://doi.org/10.1080/00071669987926 
31. Collins NE, Moran ET (1999) Influence of supplemental manganese and zinc on live performance and carcass quality of broilers. J Appl Poult Res 8(2):222-227. https://doi.org/10.1093/japr/8.2. 222

32. Rossi P, Rutz F, Anciuti MA, Rech JL, Zauk NHF (2007) Influence of graded levels of organic zinc on growth performance and carcass traits of broilers. J Appl Poult Res 16(2):219-225. https:// doi.org/10.1093/japr/16.2.219

33. Wen M, Wu B, Zhao H, Liu G, Chen X, Tian G, Cai J, Jia G (2019) Effects of dietary zinc on carcass traits, meat quality, antioxidant status, and tissue zinc accumulation of pekin ducks. Biol Trace Elem Res 190(1):187-196. https://doi.org/10.1007/ s12011-018-1534-4

34. Mohammadi V, Ghazanfari S, Mohammadi-Sangcheshmeh A, Nazaran MH (2015) Comparative effects of zinc-nano complexes, zinc-sulphate and zinc-methionine on performance in broiler chickens. Br Poult Sci 56(4):486-493. https://doi.org/10.1080/ 00071668.2015.1064093

35. Olukosi OA, Van Kuijk S, Han Y (2018) Copper and zinc sources and levels of zinc inclusion influence growth performance, tissue trace mineral content, and carcass yield of broiler chickens. Poult Sci 97(11):3891-3898. https://doi.org/10.3382/ps/pey247

36. Olukosi OA, Van Kuijk SJA, Han Y (2019) Sulfate and hydroxychloride trace minerals in poultry diets - comparative effects on egg production and quality in laying hens, and growth performance and oxidative stress response in broilers. Poult Sci 98(10):4961-4971. https://doi.org/10.3382/ps/pez261

37. Hawthorne FC, Sokolova E (2002) Simonkolleite, Zn5 (OH)8 $\mathrm{Cl} 2(\mathrm{H} 2 \mathrm{O})$, a decorated interrupted-sheet structure of the form [MФ2]4. Can Mineral 40(3):939-946. https://doi.org/10.3749/ gscanmin.40.3.939

38. Ao T, Pierce JL, Power R et al (2006) Evaluation of Bioplex Zn® as an organic zinc source for chicks. Int J Poult Sci 5(9):808-811. https://doi.org/10.3923/ijps.2006.808.811
39. Stahl JL, Cook ME, Sunde ML, Gregor JL (1989) Enhanced humoral immunity in progeny chicks from hens fed practical diets supplemented with zinc. Appl Agric Res 4:86-89

40. Burrell AL, Dozier WA, Davis AJ, Compton MM, Freeman ME, Vendrell PF, Ward TL (2004) Responses of broilers to dietary zinc concentrations and sources in relation to environmental implications. Br Poult Sci 45(2):225-263. https://doi.org/10.1080/00071 660410001715867

41. Jahanian R, Rasouli E (2015) Effects of dietary substitution of zinc-methionine for inorganic zinc sources on growth performance, tissue zinc accumulation and some blood parameters in broiler chicks. J Anim Physiol Anim Nutr (Berl) 99(1):50-58. https://doi.org/10.1111/jpn.12213

42. Star L, van der Klis JD, Rapp C, Ward TL (2012) Bioavailability of organic and inorganic zinc sources in male broilers. Poult Sci 91(12):3115-3120. https://doi.org/10.3382/ps.2012-02314

43. Min YN, Liu FX, Qi X, Ji S, Cui L, Wang ZP, Gao YP (2019) Effects of organic zinc on tibia quality, mineral deposit, and metallothionein expression level of aged hens. Poult Sci 98(1):366-372. https://doi.org/10.3382/ps/pey386

44. Ognik K, Stẹpniowska A, Cholewińska E, Kozłowski K (2016) The effect of administration of copper nanoparticles to chickens in drinking water on estimated intestinal absorption of iron, zinc, and calcium. Poult Sci 95(9):2045-2051. https://doi.org/10.3382/ ps/pew200

45. Rama R, Planas J (1981) Dietary cadmium effect on iron metabolism in chickens. Biol Trace Elem Res 3(3):169-183. https://doi. org/10.1007/BF02990115

46. McNab JM, Boorman KN (2002) Poultry feedstuffs: supply, composition and nutritive value. CABI Publishing Wallingford, UK. https://doi.org/10.1079/9780851994642.0000

Publisher's Note Springer Nature remains neutral with regard to jurisdictional claims in published maps and institutional affiliations. 